\title{
Comparative Phytochemical Analysis and Antioxidant Activities of Tamalakyadi Decoction with Its Modified Dosage Forms
}

\author{
Jeevani Maheshika Dahanayake, ${ }^{1}$ Pathirage Kamal Perera ${ }^{\circ},{ }^{1}$ \\ Priyadarshani Galappatty, ${ }^{2}$ Hettiarachchige Dona Sachindra Melshandi Perera, ${ }^{3}$ and \\ Liyanage Dona Ashanthi Menuka Arawwawala ${ }^{3}$ \\ ${ }^{1}$ Department Ayurveda Pharmacology and Pharmaceutics, Institute of Indigenous Medicine, University of Colombo, Sri Lanka \\ ${ }^{2}$ Department of Pharmacology, Faculty of Medicine, University of Colombo, Sri Lanka \\ ${ }^{3}$ Research and Development Complex, Industrial Technology Institute, Malabe, Sri Lanka
}

Correspondence should be addressed to Pathirage Kamal Perera; drkamalperera@yahoo.com

Received 1 February 2019; Revised 22 March 2019; Accepted 16 April 2019; Published 2 May 2019

Guest Editor: Jesus R. R. Amado

Copyright (C) 2019 Jeevani Maheshika Dahanayake et al. This is an open access article distributed under the Creative Commons Attribution License, which permits unrestricted use, distribution, and reproduction in any medium, provided the original work is properly cited.

\begin{abstract}
Background and Objective. Tamalakyadi decoction (TD) is a classical formulation mentioned in authentic traditional medicine text Sarasankshepaya under nasal diseases and used as a remedy for allergic rhinitis. It consists of 12 plant ingredients. Decoction preparations are widely used in Sri Lankan traditional system and considered effective and safe for treating many disorders. However, decoctions have to be used only in fresh state due to shorter shelf life and loss of stability. This decoction preparation method leads to decreasing the patient compliance and is also time consuming. Hence, the objective of the present study was to convert TD to consumer friendly novel dosage form, namely, freeze dried, spray dried, and traditional ganasara forms. Methodology. Therefore, we compared the phytochemical constituents and antioxidant activities of TD with its modified dosage forms. The chemical comparison of four dosage forms comprises phytochemical screening, TLC and HPTLC fingerprint profiles and the antioxidant activities by DPPH free radical scavenging activity, Ferric reducing antioxidant power (FRAP), total polyphenol content (TPC), and total flavonoid content (TFC). Results. Phytochemical screening revealed the presence of alkaloids, saponins, tannins, steroids, flavonoids, phenols, and terpenoids in all dosage forms. However, the saponins, alkaloids, flavonoids, terpenoids, and steroids were more prominent in TD and freeze dried preparation than the other two preparations. HPTLC fingerprint pattern of freeze dried dosage was more similar with HPTLC fingerprint pattern of TD in terms of number of peaks and their intensity compared to that of spray dried and ganasara dosage forms. Antioxidant activities such as DPPH, FRAP, TPC, and TFC were higher in decoction and freeze dried preparation than in spray dried and ganasara preparation. Conclusion. Freeze dried TD is the most suitable ready to use preparation having similar chemical properties and antioxidant activities to TD.
\end{abstract}

\section{Introduction}

Tamalakyadi decoction (TD) is an effective herbal decoction used for allergic rhinitis since long time. It is mentioned in authentic traditional medicine text, Sarasankshepaya, under nasa roga (nasal diseases) [1]. Allergic rhinitis is an IgE mediate immune response of the nasal mucosa against inhaled allergens and defined as symptoms of sneezing, rhinorrhea, nasal congestion, and itching of the nose and eyes. It is commonly defined as seasonal or perennial, depending upon whether symptoms are manifested at defined yearly intervals or throughout the year, respectively [2]. This condition is the most common allergic disorder and the prevalence of allergic rhinitis is estimated in the range from $9 \%$ to 42 $\%$ [3]. The symptoms of allergic rhinitis may significantly affect a patient's quality of life and can be associated with conditions such as fatigue, headache, cognitive impairment, and sleep disturbances. Appropriate management of allergic 
TABLE 1: Ingredients of Tamalakyadi decoction.

\begin{tabular}{|c|c|c|c|c|c|}
\hline & Plant name & Family & Sinhala name used in Sri Lanka & Sanskrit name & Used part \\
\hline 1 & Phyllanthus niruri L. & Phyllanthaceae & Pitawakka & Tamalaki & Whole plant \\
\hline 2 & Terminalia chebula Retz. & Combretaceae & Aralu & Haritaki & Fruit cover \\
\hline 3 & Premna herbacea Roxb. & Lamiaceae & Siritekku & Bharangi & Roots \\
\hline 4 & Piper retrofractum Vahl & Piperaceae & Siviya & Chavya & Roots \\
\hline 5 & Piper longum L. & Piperaceae & Tippili & Pippali & Fruits \\
\hline 6 & Solanum trilobatum $\mathrm{L}$. & Solanaceae & Wel Tibbatu & Vallikantakarika & Whole plant \\
\hline 7 & Tinospora cordifolia (Thunb.) Miers & Menispermaceae & Rasakinda & Guduchi & Stem \\
\hline 8 & Zingiber officinale Roscoe & Zingiberaceae & Inguru & Shunti & Dried Rhizome \\
\hline 9 & Piper nigrum L. & Piperaceae, & Gammiris & Maricha & Fruits \\
\hline 10 & Solanum melongena L. & Solanaceae & Elabatu & Vruhati & Roots \\
\hline 11 & Solanum xanthocarpum L. & Solanaceae & Katuwelbatu & Kantakari & Whole plant \\
\hline 12 & Justicia adhatoda L. & Acanthaceae & Adathoda & Vasa & Whole plant \\
\hline
\end{tabular}

rhinitis is an important component in effective management of coexisting or complicated respiratory conditions such as asthma, sinusitis, and sleep apnea [4].

In Ayurveda system of medicine, allergic rhinitis is described as Apeenasa or Peenasa and the concept of allergy is explained under "Asatmyaja vyadhi" (allergic disorders), while its effects are explained in hereditary, Viruddhahara (incompatible foods) and Dushivisha (polluted substances or allergic agents) and Ritu sandhi (seasonal changes) [5].

Effective therapeutic methods for allergic rhinitis including internal as well as external treatments are described in Sri Lankan traditional system of medicine and in Ayurveda medicine. TD is one of the effective decoctions used for allergic rhinitis. It includes 12 ingredients which are mentioned in Table 1. Among those 12 ingredients, Clerodendrum serratum (L.) Moon plant and Solanum indicum L. plant were replaced by Premna herbacea Roxb. and Solanum melongena L. plants, respectively, for many years.

Decoction is a basic Ayurveda dosage form which is one of the most commonly used and considered as very effective dosage form in system of traditional medicine. However, the decoction preparations have some drawbacks such as unpleasant taste and have to be used only in fresh state due to loss of stability [6]. Therefore, patients on treatments with decoctions need to prepare it every day which causes difficulties in their busy lifestyles. Hence in this study an approach was made to prepare ready to use user friendly decoction powder by using novel technology and choose the most similar ready to use preparation when compared with the decoction in terms of phytochemical constituents and antioxidant activity.

\section{Materials and Methods}

2.1. Collection and Authentication of Plant Materials. The plants used in TD were collected from Colombo city $\left(6^{\circ} 55^{\prime}\right.$ 54.98” N x 7950'52.01” E) Western province, Sri Lanka, between July and August 2018 and authenticated by the Curator of National Herbarium of Peradeniya, Sri Lanka. The contaminants of the raw materials were removed manually, washed with water, and shade dried. Then dried raw materials were crushed to a coarse powder separately and stored in tightly closed containers.

2.2. Preparation Method of Tamalakyadi Decoction (TD). TD was prepared according to the traditional decoction preparation method [7]. Five grams was taken from each ingredient of the formulation and boiled with $1920 \mathrm{ml}$ of water under mild flame to reduce the volume up to $240 \mathrm{ml}$. Then the decoction was filtered through a single folded cotton cloth and collected to a separate vessel. Same procedure was repeated for eight times and pooled decoction $(240 \mathrm{ml} \times 8)$ was divided equally $(240 \mathrm{ml} \times 2)$ into four portions. The fist portion was labeled as TD and others were subjected to prepare modified dosage forms.

2.3. Preparation of Freeze Dried Form of Tamalakyadi Decoction (FDF-TD). TD $(240 \mathrm{ml} \times 2)$ was freeze dried using a freeze dryer (Telstar LyoBeta) with the temperature $-45^{\circ} \mathrm{C}$ to $40^{\circ} \mathrm{C}$ and kept in a refrigerator (at $4^{\circ} \mathrm{C}$ ) until used.

2.4. Preparation of Spray Dried Form of Tamalakyadi Decoction (SDF-TD). TD $(240 \mathrm{ml} \times 2)$ was spray dried using a spray dryer (Mini Spray drier B-290 BUCHI) with $180^{\circ} \mathrm{C}$ inlet temperature, $102^{\circ} \mathrm{C}$ outlet temperature, and $50 \mathrm{~kg}$ of feed pressure.

2.5. Preparation of Ganasara Form of Tamalakyadi Decoction (GSF-TD). TD $(240 \mathrm{ml} \times 2)$ was subjected to mild heat, converted to semisolid form, and oven dried (at $105^{\circ} \mathrm{C}$ ) to prepare the GSF-TD [8].

2.6. Phytochemical Screening. Phytochemical screening was carried out according to the methods described by Goveas [9] and Joanne and coworkers [10] with some modifications. In brief, freshly prepared TD $(240 \mathrm{ml} \times 2)$ and the FDF-TD, SDFTD, and GSF-TD samples dissolved in hot water $(240 \mathrm{ml} \times 2)$ separately were subjected to phytochemical screening studies as follows.

2.7. Test for Saponins. Five milliliters of extract and $2.5 \mathrm{ml}$ of water were added to a test tube, shaken vigorously, and kept 
for 10 minutes. Then the froth was mixed with 3 drops of olive oil and shaken vigorously and the formation of emulsion was observed. The presence of stable froth indicates that saponins are found in the extract.

\subsection{Tests for Tannins}

(a) Ferric chloride test: five drops of $\mathrm{Fecl}_{3}$ was added to each extract and mixed well. Appearance of a black precipitate indicates the presence of tannins.

(b) Lead acetate test: three drops of $\mathrm{Pb}(\mathrm{OAc})_{2}$ was added to $5 \mathrm{ml}$ of extract and mixed well. Formation of a yellow precipitate is indicative of tannins.

(c) Vanillin test: few drops of $10 \%$ vanillin in ethyl alcohol and conc. $\mathrm{HCl}$ were added to each extract and mixed well. Appearance of red color indicates the presence of tannins.

\subsection{Test for Phenols}

(a) Vanillin test: few drops of $10 \%$ vanillin in ethyl alcohol and conc. $\mathrm{HCl}$ were added to $2 \mathrm{ml}$ of extract. Appearance of red color indicates the presence of phenols.

(b) Lead acetate test: three drops of $\mathrm{Pb}(\mathrm{OAc})_{2}$ was added to $5 \mathrm{ml}$ of extract and mixed well. Formation of yellow precipitate indicates the presence of phenols.

\subsection{Test for Alkaloids}

(a) Picric acid test: few drops of picric acid was added to $5 \mathrm{ml}$ of extract and mixed well. Formation of a yellow color crystalline precipitate indicates the presence of alkaloids.

(b) Tannic acid test: few drops of tannic was added to 5 $\mathrm{ml}$ of extract and mixed well. Formation of a yellow color crystalline precipitate indicates the presence of alkaloids.

(c) Wagner reagent test: two drops of Wagner reagent was added to $2 \mathrm{ml}$ of extract and mixed well. Appearance of a reddish color indicates the presence of alkaloids.

\subsection{Test for Flavonoids}

(a) Five milliliters of dilute ammonia solution was added to $5 \mathrm{ml}$ of extract followed by the addition of conc. $\mathrm{H}_{2} \mathrm{SO}_{4}$. Appearance of yellow color indicates the presence of flavonoids.

(b) Five milliliters of extract was added to a test tube containing piece of metallic mg and 3 drops of conc. $\mathrm{HCl}$ and heated. Flavonoids give a red-orange color.

\subsection{Test for Terpenoids}

(a) Salkowski test: extract $(5 \mathrm{ml})$ was mixed with $2 \mathrm{ml}$ of chloroform in a test tube and $3 \mathrm{ml}$ of conc. $\mathrm{H}_{2} \mathrm{SO}_{4}$ was added along the sides of the test tube. Formation of reddish brown color is an indicative of presence of terpenoids.

(b) Test for sesquiterpenes: one milliliter of conc. $\mathrm{H}_{2} \mathrm{SO}_{4}$ was added to $2 \mathrm{ml}$ of extract and mixed well. A reddish brown color indicates the presence of terpenoids.

\subsection{Test for Steroids}

(a) Five milliliters of acetic anhydride and $5 \mathrm{ml}$ of conc. $\mathrm{H}_{2} \mathrm{SO}_{4}$ were added to the $5 \mathrm{ml}$ of extract and mixed well. A color change from violet to blue or green color indicates the presence of steroids.

(b) Lieberman Burchard test reaction: two milliliters of acetic anhydride and $2 \mathrm{ml}$ of conc. $\mathrm{H}_{2} \mathrm{SO}_{4}$ were added to $2 \mathrm{ml}$ of extract and mixed well. Formation of a dark bluish green color indicates the presence of steroids.

2.14. Test for Cardiac Glycosides. One milliliter of glacial acetic acid was added to $3 \mathrm{ml}$ of extract and con. $\mathrm{H}_{2} \mathrm{SO}_{4}$ acid was introduced to the bottom of the tube. A reddish brown or violet brown ring at the interface of the two liquids indicates the presence of cardiac glycosides.

2.15. Development of Thin Layer Chromatography (TLC) and High Performance Thin Layer Chromatography (HPTLC) Fingerprints. Freshly prepared TD $(100 \mathrm{ml})$ and FDF-TD, SDF-TD and GSF-TD dosage forms dissolved in hot water (100 ml from each) were added separately to a separating funnel containing $50 \mathrm{ml}$ of dichloromethane, mixed well and kept for $20 \mathrm{~min}$. After that, dichloromethane layer was separated. This was done thrice and collected dichloromethane fractions were pooled and evaporated to dryness. Dried dichloromethane fractions of TD, FDF-TD, SDF-TD, and GSF-TD dosage forms were redissolved in $5 \mathrm{ml}$ of dichloromethane separately and spotted on a TLC plate. TLC fingerprint profile was developed for all fractions using dichloromethane, ethyl acetate, and cyclohexane in a ratio of 3:0.5:1.5 v/v. The plate was visualized under UV radiation (both $254 \mathrm{~nm}$ and $366 \mathrm{~nm}$ ) and HPTLC fingerprint patterns were observed by using CAMAG - HPTLC scanner.

2.16. Extracts for In Vitro Antioxidant Assays. The powders obtained from freeze drying, spray drying, and ganasara methods were dissolved in methanol to prepare methanolic extracts. Liquid form decoction was dried by evaporation using rotary evaporator and redissolved in methanol.

2.17. Antioxidants Assay. The antioxidant activities of these four preparations were assessed by using $\mathrm{DPPH}$ free radical scavenging activity, Ferric reducing antioxidant power (FRAP), total polyphenol content (TPC), and total flavonoid content (TFC).

2.18. DPPH Free Radical Scavenging Activity. The DPPH free radical scavenging assay was performed according to the method described by Blois, [11] with some modifications in 96-well microplates. Reaction mixture of $200 \mu$ l, containing $150 \mu \mathrm{l}$ of DPPH solution and $50 \mu \mathrm{l}$ of each extract (dissolved 
in methanol) of decoction or freeze dried or spray dried or ganasara was incubated at room temperature $\left(25 \pm 2^{\circ} \mathrm{C}\right)$ for 10 minutes in dark and the absorbance was recorded at 517 $\mathrm{nm}$. Five different concentrations of Trolox $(2.5,5,10,20,30$ $\mu \mathrm{g} / \mathrm{ml}$ ) were used to construct the standard curve. Results were expressed as $\mathrm{IC}_{50} ; \mu \mathrm{g} / \mathrm{ml}$.

2.19. Ferric Reducing Antioxidant Power (FRAP). The assay was carried out according to the Benzie and Strain [12] with some modifications in 96-well microplates. The working FRAP reagent was prepared by mixing $300 \mathrm{mM}$ acetate buffer (pH 3.6), $10 \mathrm{mM}$ TPTZ solution and $20 \mathrm{mM} \mathrm{FeCl}_{3} \cdot 6 \mathrm{H}_{2} \mathrm{O}$ $(10: 1: 1 \mathrm{v} / \mathrm{v} / \mathrm{v})$ just before use and incubated at $37^{\circ} \mathrm{C}$ for 8 minutes. Reaction mixtures of $200 \mu \mathrm{l}$ containing $150 \mu \mathrm{l}$ FRAP reagent, $30 \mu \mathrm{l}$ of acetate buffer, and $20 \mu \mathrm{l}$ of four extracts (120 $\mu \mathrm{g} / \mathrm{ml})$ were incubated at room temperature $\left(25 \pm 2^{\circ} \mathrm{C}\right)$ for 8 minutes and the absorbance was recorded at $600 \mathrm{~nm}$. Six different concentrations of Trolox $(10.3125,20.625,41.25,83.5$, $167 \mu \mathrm{g} / \mathrm{ml}$ ) were used to construct the standard curve. Results were expressed as $\mathrm{mg}$ TE/g of extract.

2.20. Total Polyphenol Content (TPC). Total polyphenol content of four extracts was determined by the Folin-Ciocalteu spectrophotometric method adopted from Singleton and Rossi [13] by using gallic acid as standard phenolic compound using 96-well microplates. Twenty microliters of four extracts, each dissolved in distilled water $(150 \mu \mathrm{g} / \mathrm{ml})$, were added to $110 \mu \mathrm{l}$ of ten times diluted freshly prepared FolinCiocalteu reagent and incubated with $70 \mu \mathrm{l}$ of $10 \%$ sodium carbonate solution at room temperature $\left(25 \pm 2^{\circ} \mathrm{C}\right)$ for 30 minutes and the absorbance was recorded at $765 \mathrm{~nm}$. Five different concentrations of gallic acid $(0.78,1.562,3.125,6.25$, $12.5,25$, and $50 \mathrm{mg} / \mathrm{ml}$ ) were used to construct the standard curve. Total Polyphenol Content was expressed as mg Gallic Acid Equivalents (GAF)/g of extract.

2.21. Total Flavonoid Content of (TFC). Total flavonoid content of four samples was determined by Aluminium chloride method [14]. One hundred microliters of $2 \%$ Aluminium chloride in methanol solution was incubated with $100 \mu \mathrm{l}$ of four samples dissolved in methanol $(120 \mu \mathrm{g} / \mathrm{ml})$ at room temperature $\left(25 \pm 2^{\circ} \mathrm{C}\right)$ for 10 minutes and absorbance was recorded at $415 \mathrm{~nm}$. Six different concentrations of Quercetin $(1,2,4,8,16,32 \mu \mathrm{g} / \mathrm{ml})$ were used to construct the standard curve. Total Flavonoid Content was expressed as mg Quercetin Equivalents (QE)/g of extract.

2.22. Statistical Analysis. All the assays were performed four times and the absorbance was presented as Mean \pm SEM. Analysis of variance was performed using SPSS procedures. The level of significance was used for comparison at 0.05 levels. SPSS $t$ - test was used for testing significance level between in other.

\section{Results and Discussion}

In Ayurveda system of medicine we can identify various medicinal preparations mentioned under Bhaishajya Kalpana [15]. Decoctions (kashaya), vati (pills), powders (churna), oils (taila), and arishta-asava (fermented preparations) are few examples for them. These drug preparations can be classified into two: primary preparations and secondary preparations. Panchavidha Kashaya Kalpana is considered as primary preparations which include five types of liquid preparations that are therapeutically effective. These primary preparations are commonly used as the initial dosage forms in treatment and as the base for the different medicinal preparations.

Decoction is one of the effective dosage forms widely used in Ayurveda treatment and the shelf life of this preparation is 24 hours, which means, in the treatment, patient should prepare the decoction everyday [16]. If we are able to develop novel products from decoctions having long shelf life, that would be convenient for people. However, in order to fulfill this requirement, potency of the preparation should be same as the traditional formulation. Potency of a medicine is critical for its efficacy. When modifying the preparation to an easy to use dosage form with appropriate shelf life, active principles or phytochemicals of the drug have to be protected as the traditional preparation.

In this study qualitative phytochemical analysis was done to detect and compare the chemical constituents of TD and its modified dosage forms. Most of the phytochemicals including saponins, alkaloids, flavonoids, phenols, terpenoids, tannins, and steroids were present in all four types of preparations (Table 2). However, saponins, alkaloids, flavonoids, terpenoids, and steroids were more prominent in both traditional TD and FDF-TD than the SDF-TD and GSF-TD. Plant secondary metabolites such as phenols, flavonoids, tannins, and saponins are responsible for many activities including antioxidants, anti-inflammatory, antibacterial, antiasthmatic, immunomodulatory actions etc. [17]. Prolonged administration of saponin from Clerodendrum serratum plant has been reported to exhibit antihistaminic and antiallergic activity $[18,19]$. C. serratum is one of the ingredients in TD and high content of saponins was found in both TD and FDF-TD. This factor helps to prove the effectiveness of TD and FDF-TD in the treatment of allergic rhinitis which is characterized by nasal congestion, watery nasal discharge, itching of the nose, and sneezing [20]. Therefore, the above properties of the drug could overcome the symptoms of allergic rhinitis. Further this is the first attempt taking place to screen possible phytochemicals present in TD.

TLC and HPTLC techniques are used for quality assessment in Ayurvedic preparations. These methods are widely employed in pharmaceutical industry in process of identification, development and quality control of herbal products [21]. However, HPTLC technique is more advanced than TLC and used for quantification purpose. When considering the TLC fingerprint patterns almost similar TLC profiles were observed in all four dosage forms bearing $\mathrm{R}_{\mathrm{f}}$ values of 0.12 , $0.32,0.43,0.59,0.70$, and 0.93 (at $245 \mathrm{~nm}$ ). However, one additional spot was observed in TD bearing $R_{f}$ value of 0.26 (at $366 \mathrm{~nm}$ ) (Figure 1). 
TABLE 2: Phytochemical screening of Tamalakyadi decoction and its modified dosage forms.

\begin{tabular}{|c|c|c|c|c|c|}
\hline Phyto constituents & Test & $\mathrm{TD}$ & FDF-TD & SDF-TD & GSF-TD \\
\hline Saponins & Frothing test & $\begin{array}{l}+++ \\
\text { High }\end{array}$ & $\begin{array}{l}+++ \\
\text { High }\end{array}$ & $\begin{array}{c}+ \\
\text { Present } \\
\end{array}$ & $\begin{array}{c}++ \\
\text { Moderate }\end{array}$ \\
\hline \multirow[t]{3}{*}{ Tannins } & $\mathrm{FeCl}_{3}$ test & $\begin{array}{c}\text { +++ } \\
\text { (Blue black } \\
\text { precipitate) }\end{array}$ & $\begin{array}{c}+++ \\
\text { (Blue black } \\
\text { precipitate) }\end{array}$ & $\begin{array}{c}+++ \\
\text { (Blue black } \\
\text { precipitate) }\end{array}$ & $\begin{array}{c}\text { +++ } \\
\text { (Blue black } \\
\text { precipitate) }\end{array}$ \\
\hline & Vanillin test & \multicolumn{4}{|c|}{ Negative } \\
\hline & $\mathrm{Pb}(\mathrm{OAc})_{2}$ test & $\begin{array}{c}+++ \\
\text { (Yellow } \\
\text { precipitate) } \\
\end{array}$ & $\begin{array}{c}++ \\
\text { (Yellow } \\
\text { precipitate) } \\
\end{array}$ & $\begin{array}{c}+++ \\
\text { (Yellow } \\
\text { precipitate) } \\
\end{array}$ & $\begin{array}{c}++ \\
\text { (Yellow } \\
\text { precipitate) }\end{array}$ \\
\hline \multirow[t]{2}{*}{ Phenols } & Vanillin test & Negative & & & \\
\hline & $\mathrm{Pb}(\mathrm{OAc})_{2}$ test & $\begin{array}{c}+++ \\
\text { (Yellow } \\
\text { precipitate) } \\
\end{array}$ & $\begin{array}{c}++ \\
\text { (Yellow } \\
\text { precipitate) } \\
\end{array}$ & $\begin{array}{c}+++ \\
\text { (Yellow } \\
\text { precipitate) } \\
\end{array}$ & $\begin{array}{c}++ \\
\text { (Yellow } \\
\text { precipitate) } \\
\end{array}$ \\
\hline \multirow[t]{3}{*}{ Alkaloids } & Tannic acid test & $\begin{array}{c}++ \\
\text { (yellow } \\
\text { precipitate) }\end{array}$ & $\begin{array}{c}++ \\
\text { (yellow } \\
\text { precipitate) }\end{array}$ & $\begin{array}{c}+ \\
\text { (yellow } \\
\text { precipitate) }\end{array}$ & $\begin{array}{c}++ \\
\text { (yellow } \\
\text { precipitate) }\end{array}$ \\
\hline & Picric acid test & $\begin{array}{c}++ \\
\text { (yellow } \\
\text { precipitate) } \\
\end{array}$ & $\begin{array}{c}+++ \\
\text { (yellow } \\
\text { precipitate) } \\
\end{array}$ & $\begin{array}{c}+ \\
\text { (yellow } \\
\text { precipitate) } \\
\end{array}$ & $\begin{array}{c}++ \\
\text { (yellow } \\
\text { precipitate) } \\
\end{array}$ \\
\hline & Wagner test & $\begin{array}{c}+++ \\
\text { (red colour) } \\
\end{array}$ & $\begin{array}{c}+++ \\
\text { (red colour) } \\
\end{array}$ & $\begin{array}{c}++ \\
\text { (red colour) } \\
\end{array}$ & $\begin{array}{c}++ \\
\text { (red colour) } \\
\end{array}$ \\
\hline \multirow[t]{2}{*}{ Flavonoids } & Test (a) & $\begin{array}{c}+++ \\
\text { (Yellow colour) }\end{array}$ & $\begin{array}{c}+++ \\
\text { (Yellow colour) }\end{array}$ & $\begin{array}{c}++ \\
\text { (Yellow colour) } \\
\end{array}$ & $\begin{array}{c}++ \\
\text { (Yellow colour) }\end{array}$ \\
\hline & Test (b) & $\begin{array}{c}++ \\
\text { (Orange } \\
\text { colour) } \\
\end{array}$ & $\begin{array}{c}+++ \\
\text { (Orange } \\
\text { colour) } \\
\end{array}$ & $\begin{array}{c}+ \\
\text { (Orange } \\
\text { colour) } \\
\end{array}$ & $\begin{array}{c}++ \\
\text { (Orange } \\
\text { colour) } \\
\end{array}$ \\
\hline \multirow[t]{2}{*}{ Terpenoids } & Salkowski test & $\begin{array}{c}+++ \\
\text { (reddish } \\
\text { brown colour) }\end{array}$ & $\begin{array}{c}+++ \\
\text { (reddish } \\
\text { brown colour) }\end{array}$ & $\begin{array}{c}++ \\
\text { (reddish } \\
\text { brown colour) }\end{array}$ & $\begin{array}{c}++ \\
\text { (reddish } \\
\text { brown colour) }\end{array}$ \\
\hline & Sesquiterpenes test & $\begin{array}{c}++ \\
\text { (reddish } \\
\text { brown colour) }\end{array}$ & $\begin{array}{c}++ \\
\text { (reddish } \\
\text { brown colour) }\end{array}$ & $\begin{array}{c}+ \\
\text { (reddish } \\
\text { brown colour) }\end{array}$ & $\begin{array}{c}++ \\
\text { (reddish } \\
\text { brown colour) }\end{array}$ \\
\hline \multirow[t]{2}{*}{ Steroids } & Test (a) & $\begin{array}{c}+++ \\
\text { (violet colour) }\end{array}$ & $\begin{array}{c}+++ \\
\text { (violet colour) }\end{array}$ & $\begin{array}{c}++ \\
\text { (violet colour) } \\
\end{array}$ & $\begin{array}{c}++ \\
\text { (violet colour) }\end{array}$ \\
\hline & Liebermann Burchard Test & $\begin{array}{c}++ \\
\text { (Dark bluish } \\
\text { green colour) } \\
\end{array}$ & $\begin{array}{c}+++ \\
\text { (Dark bluish } \\
\text { green colour) } \\
\end{array}$ & $\begin{array}{c}++ \\
\text { (Dark bluish } \\
\text { green colour) } \\
\end{array}$ & $\begin{array}{c}++ \\
\text { (Dark bluish } \\
\text { green colour) } \\
\end{array}$ \\
\hline Cardiac glycosides & & $\begin{array}{l}\text { Reddish brown } \\
\text { ring formed }\end{array}$ & $\begin{array}{l}\text { Reddish brown } \\
\text { ring formed }\end{array}$ & $\begin{array}{l}\text { Reddish brown } \\
\text { ring formed }\end{array}$ & $\begin{array}{l}\text { Reddish brown } \\
\text { ring formed }\end{array}$ \\
\hline
\end{tabular}

-ve: negative, +: positive in low level, ++: positive in moderate level, +++: positive in high level.

TD: Tamalakyadi Decoction, FDF-TD: Freeze Dried Form of Tamalakyadi Decoction, SDF-TD: Spray Dried Form of Tamalakyadi Decoction, GSF-TD: Ganasara Form of Tamalakyadi Decoction.

HPTLC study was carried out to compare the area and intensity of the spots appeared in TLC profiles of four preparations. HPTLC fingerprint pattern of TD was similar to that of FDF-TD in terms of number of peaks and their intensity compared to that of SDF-TD and GSF-TD (Figure 2). This may be due to the temperature and time which affect chemical constituents of plant materials during drug preparation. Decomposition of chemical constituents or change in chemical structure or reduction of chemical constituents occurred when increasing the temperature and time [22-26]. TD is the traditional preparation and all the modified dosage forms are made out of it. Therefore, FDF-TD, SDF-TD, and GSF-TD initially subjected to $105^{\circ} \mathrm{C}$. However, FDF-TD will not be exposed more than $105^{\circ} \mathrm{C}$ as we used the freeze drying process while SDF-TD will be exposed to $180^{\circ} \mathrm{C}$ during the preparation of modifies dosage form. When preparation of GSF-TD will not be exposed more than $105^{\circ} \mathrm{C}$ but it has to keep prolong time in $105^{\circ} \mathrm{C}$. Therefore, heat labile compound/s in both SDF-TD and GSF-TD may be decomposed during the preparation of modified dosage forms. This may be the reason that the chemical profile of FDF-TD was similar to that of TD. In contrast, research 


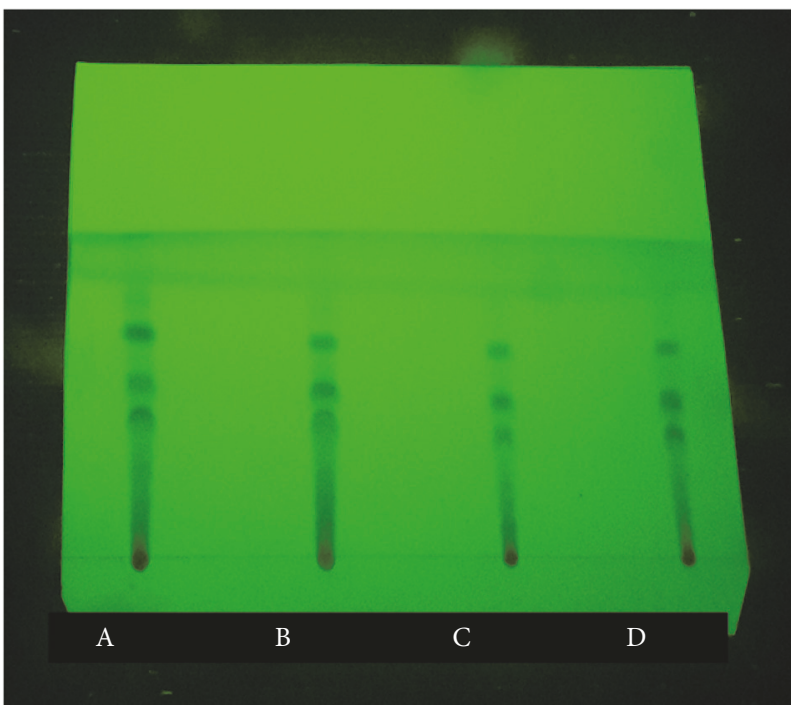

Figure 1: TLC fingerprint profiles of Tamalakyadi Decoction and its modified dosage forms. A: Tamalakyadi decoction (TD), B: Freeze Dried Form of Tamalakyadi Decoction (FDF-TD), C: Spray Dried Form of Tamalakyadi Decoction (SDF-TD), D: Ganasara Form of Tamalakyadi Decoction (GSF-TD).

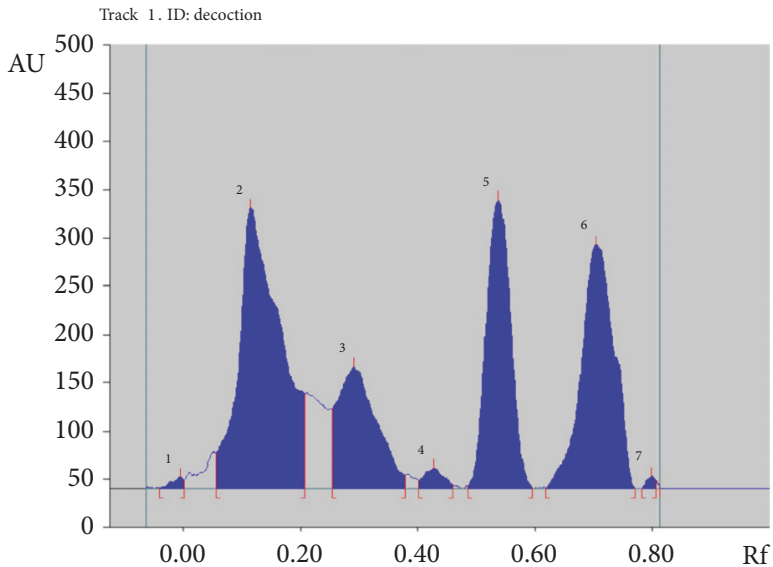

Tamalakyadi decoction

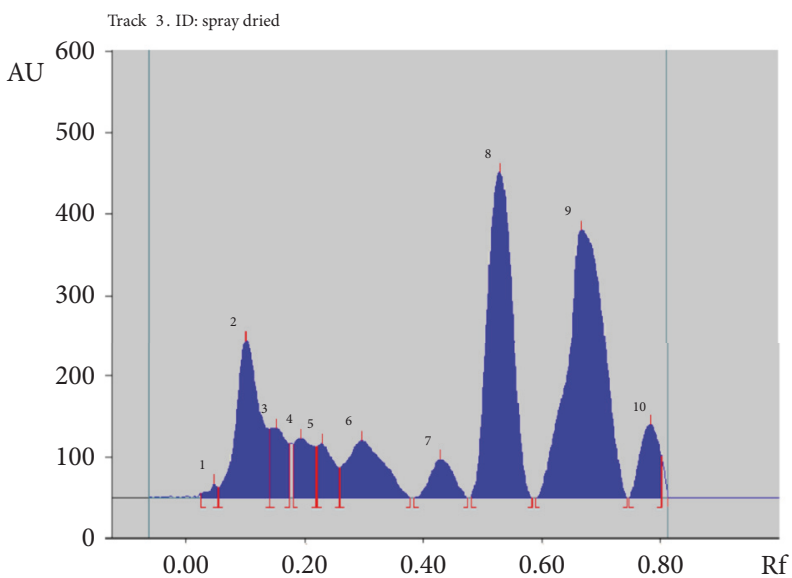

Spray Dried Form of Tamalakyadi Decoction

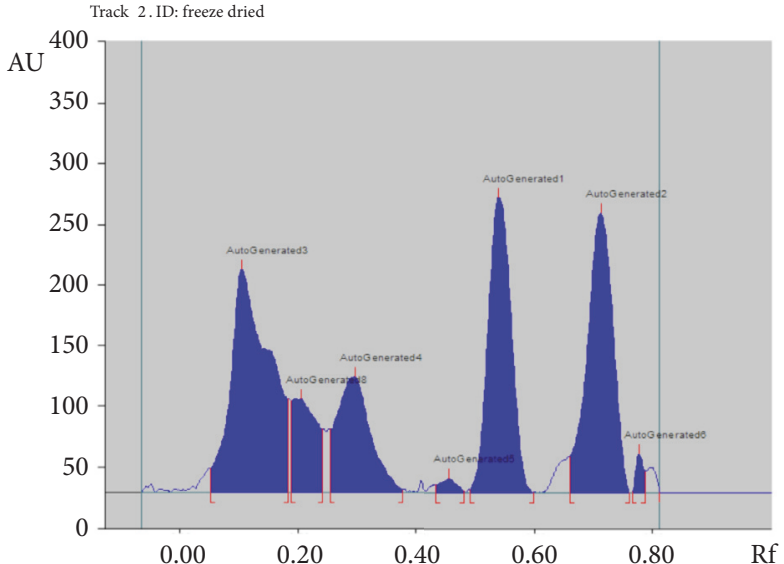

Freeze Dried Form of Tamalakyadi Decoction

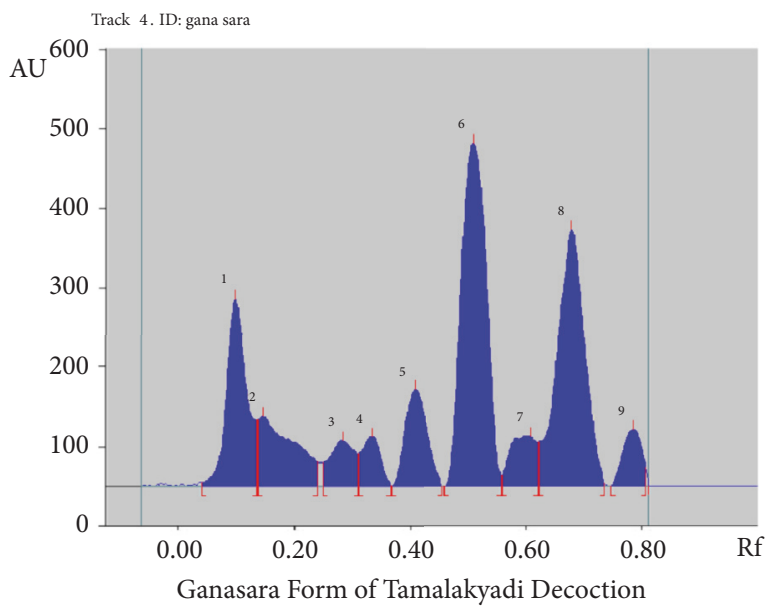

FIGURE 2: HPTLC fingerprint profiles of Tamalakyadi decoction and its modified dosage forms. 
TABLe 3: Antioxidant activities of Tamalakyadi decoction and its modified dosage forms.

\begin{tabular}{|c|c|c|c|c|}
\hline Extract & $\begin{array}{c}\text { DPPH free radical } \\
\text { scavenging } \\
\text { activity } \\
\left(\mathrm{IC}_{50} ; \mu \mathrm{g} / \mathrm{mL}\right)\end{array}$ & $\begin{array}{c}\text { FRAP } \\
\text { (mg TE/g of } \\
\text { extract) }\end{array}$ & $\begin{array}{c}\text { TPC } \\
\text { (mg GAE/g of } \\
\text { extract) }\end{array}$ & $\begin{array}{c}\text { TFC } \\
\text { (mg QE/g of } \\
\text { extract) }\end{array}$ \\
\hline Tamalakyadi Decoction & $8.2 \pm 0.1^{\mathrm{a}}$ & $572.5 \pm 2.3^{\text {aa }}$ & $206.0 \pm 2.3^{\text {aal }}$ & $8.2 \pm 0.5^{\mathrm{a} 2}$ \\
\hline $\begin{array}{l}\text { Freeze Dried Form of } \\
\text { Tamalakyadi Decoction }\end{array}$ & $10.6 \pm 0.3^{\mathrm{b}}$ & $634.2 \pm 1.3^{\mathrm{bb}}$ & $148.2 \pm 0.7^{\mathrm{bb} 1}$ & $6.2 \pm 0.3^{\mathrm{bb} 2}$ \\
\hline $\begin{array}{l}\text { Spray Dried Form of } \\
\text { Tamalakyadi Decoction }\end{array}$ & $20.8 \pm 0.3^{c}$ & $154.8 \pm 1.9^{c c}$ & $63.8 \pm 2.0^{\mathrm{ccl}}$ & $2.9 \pm 0.1^{\mathrm{cc} 2}$ \\
\hline $\begin{array}{l}\text { Ganasara Form of } \\
\text { Tamalakyadi Decoction }\end{array}$ & $17.9 \pm 0.6^{\mathrm{d}}$ & $222.4 \pm 1.0^{\mathrm{dd}}$ & $69.5 \pm 0.4^{\mathrm{dd} 1}$ & $2.9 \pm 0.1^{\mathrm{dd} 2}$ \\
\hline Trolox (standard) & $5.35 \pm 0.25^{\mathrm{e}}$ & - & - & - \\
\hline
\end{tabular}

Results are presented as Mean \pm SEM $(n=4)$.

Values with the different scripts are significantly different $\mathrm{P} \leq 0.05$ from each other.

TE: Trolox Equivalents, GAE: Gallic Acid Equivalents, QE: Quercetin Equivalents.

findings of Singh and coworkers [27] showed that spray dried form of Lodhradi Kashaya was chemically similar to that of conventional dosage form which was prepared according to the classical method mentioned in Sharangadhara Samhita. Different temperatures used in spray drying in different studies may have accounted for this. The freeze dried dosage form is exposed to low temperature $\left(-40^{\circ} \mathrm{C}\right.$ to $\left.40^{\circ} \mathrm{C}\right)$ which may cause less damage to phytoconstituents. Research reports revealed, when compared to air drying/oven drying methods, freeze drying improved the retention of phytochemicals during processing and in some cases it even increased the concentration of phytochemicals blue berry and raspberry $[28,29]$.

Antioxidants are compounds that inhibit or delay onset of oxidation and may be classified as natural or synthetic [30]. There is an increasing demand for natural antioxidants for curing and prevention of diseases indicating that compounds in natural formulations are more active than their isolated form [31]. During the recent years many changes have occurred in the management of allergic rhinitis by using medicines in various traditional medicinal systems $[32,33]$. A number of scientific investigations have proven the association between antioxidants and allergic diseases and antioxidant intake seems to have a protective effect on allergic diseases like rhinitis [34-36]. Hence in this study we had examined the antioxidant activities of four preparations to detect most similar antioxidant activity with the TD (Table 3). TD exhibited highest antioxidant activity in terms of capability of scavenging DPPH radicals, ferric reducing antioxidant power, and total phenolic and flavonoid contents (Table 3). Further, among the modified dosage forms, FDF-TD showed the best antioxidant activity and more closer to that of TD. The reason for the reduction of antioxidant activities of SDF-TD and GSF-TD may be due to the temperature used in the drug processing. Recent research findings highlighted that the temperature had an influence on antioxidant activities of the plant materials and degradation of heat sensitive compounds reported to be minimized at the low temperature [37]. Further, the temperature had an effect on total flavonoids and phenolic contents of the plant which have major contribution to the radical scavenging activity [38-40]. Among the four preparations, total flavonoids and phenolic contents are high in TD and therefore it indicated more DPPH radical scavenging activity than the three modified preparations. Also antioxidant assay results showed that the FRAP value is highest in FDF-TD. Similar results were observed in freeze dried samples of leaves and berries of Cayratia trifolia [41] and spearmint leaves [42]. This may be due to the formation of ice crystals within the tissue matrix during the freeze drying process which can rupture the cell structure, which allows the exit of cellular components and the access of solvent [43]. Hence it can perform more antioxidant potency in the media.

\section{Conclusion}

Phytochemical studies, HPTLC patterns, and antioxidant studies showed that the FDF- TD is more similar to TD which was prepared according to traditional method. Therefore, FDF-TD can be used as a novel dosage form to treat allergic rhinitis. However, clinical evaluation is needed for further confirmation.

\section{Data Availability}

The data used to support the findings of this study are available from the corresponding author upon request.

\section{Conflicts of Interest}

The authors declare that they have no conflicts of interest.

\section{Acknowledgments}

This project was funded by the University Grant Commission, Sri Lanka (UGC/VCDRIC/PG2016(II)/IIM/02, 02.02.2017). 


\section{References}

[1] A. Kumarasinghe, Vaidyaka Sarasankshepaya of Rajaguru Sri Chandra, Department of Ayurveda, Sri Lanka, 1984.

[2] D. P. Skoner, "Allergic rhinitis: Definition, epidemiology, pathophysiology, detection, and diagnosis," The Journal of Allergy and Clinical Immunology, vol. 108, no. 1, pp. S2-S8, 2001.

[3] H. A. Sampson, "Epidemiology of allergic rhinitis throughout the world," in Global atlas of allergic rhinitis and chronic rhino sinusitis, pp. 62-63, European academy of allergy and clinical immunology, 2015.

[4] P. Small, P. K. Keith, and H. Kim, "Allergic rhinitis," Allergy, Asthma \& Clinical Immunology, vol. 14, no. S2, pp. 31-41, 2018.

[5] S. Tripathi, Yogarathnakara, Chaukhambha Ayurveda Series, India, 1998.

[6] A. Verma, H. Janani, S. Yadav, Galib., and P. K. Prajapati, "Pharmaceutical and analytical studies on guduchi kwatha prepared by varying proportions of water," Journal of Ayurvedic and Herbal Medicine, vol. 2, no. 4, pp. 125-130, 2016.

[7] "Ayurveda Aushadha Sangrahaya," Department of Ayurveda, Sri Lanka, 1976.

[8] V. K. Singh and K. R. C. Reddy, "Standardization of modified dosage form of Lodhradi Kashaya prepared by two different techniques," Asian Journal of Pharmaceutics, vol. 10, no. 2, pp. S134-S138, 2016.

[9] S. W. Goveas and A. Abraham, "Extraction and secondary metabolite analysis of coscinium fenestratum (Gaertn.) Colebr: an important medicinal plant of western ghats," International Journal of Pharmaceutical Sciences and Research, vol. 5, no. 8, pp. 3484-3489, 2014.

[10] T. J. Joanne, H. A. Ashwini, and K. G. Singh, "Qualitative and quantitative phytochemical analysis of ethnomedical folklore plant Clerodendrum colebrooianum," Journal of Global Biosciences, vol. 5, no. 1, pp. 3559-3566, 2016.

[11] M. S. Blois, "Antioxidant determination by use of stable free radical," Nature, vol. 181, no. 4617, pp. 1199-1200, 1958.

[12] I. F. F. Benzie and Y. T. Szeto, "Total antioxidant capacity of teas by the ferric reducing/antioxidant power assay," Journal of Agricultural and Food Chemistry, vol. 47, no. 2, pp. 633-636, 1999.

[13] V. L. Singleton, R. Orthofer, and R. M. Lamuela-Raventós, "Analysis of total phenols and other oxidation substrates and antioxidants by means of folin-ciocalteu reagent," Methods in Enzymology, vol. 299, pp. 152-178, 1999.

[14] A. Meda, C. E. Lamien, M. Romito, J. Millogo, and O. G. Nacoulma, "Determination of the total phenolic, flavonoid and proline contents in Burkina Fasan honey, as well as their radical scavenging activity," Food Chemistry, vol. 91, no. 3, pp. 571-577, 2005.

[15] B. T. Sharangdhar, Sharangadhar Samhita, Chaukhambha Surbharati Prakashan, Varanasi, 2010.

[16] K. R. C. Reddy, Ocean of Ayurvedic Pharmaceutics, Chaukhambha Sanskrit, Bhawan, India, 2007.

[17] D. Lin, M. Xiao, J. Zhao et al., "An overview of plant phenolic compounds and their importance in human nutrition and management of type 2 diabetes," Molecules, vol. 21, no. 10, article 1374, 2016.

[18] S. S. Gupta, "Development of antihistamine and anti-allergic activity after prolonged administration of a plant saponin from Clerodendron serratum," Journal of Pharmacy and Pharmacology, vol. 20, no. 10, pp. 801-802, 1968.
[19] L. C. Mishra, "Allergic reactions," in Scientific Basis for Ayurvedic Therapies, pp. 203-207, CRC Press, USA, 2004.

[20] B. Walker, N. R. Colledge, S. Ralston, and I. Penman, Davidson's Principles and Practice of Medicine, Churchill Livingstone, New York, NY, USA, 22nd edition, 2014.

[21] K. Soni and T. Navad, "HPTLC-its application in herbal drug industry," The Pharma Review, vol. 4, pp. 112-117, 2010.

[22] F. Namjooyan, H. Hejazi, and Z. Ramezani, "Evaluation of drying process on the composition of black pepper ethanolic extract by high performance liquid chromatography with diode array detector," Jundishapur Journal of Natural Pharmaceutical Products, vol. 7, no. 4, pp. 163-167, 2012.

[23] H. Mahanom, A. H. Azizah, and M. H. Dzulkifly, "Effect of different drying methods on concentrations of several phytochemicals in herbal preparation of 8 medicinal plants leaves," Malaysian Journal of Nutrition, vol. 5, pp. 47-54, 1999.

[24] G. Rajkumar, S. Shanmugam, M. D. S. Galvâo et al., "Comparative evaluation of physical properties and volatiles profile of cabbages subjected to hot air and freeze drying," LWT- Food Science and Technology, vol. 80, pp. 501-509, 2017.

[25] Y. Li, Y. Hong, Y. Han, Y. Wang, and L. Xia, "Chemical characterization and antioxidant activities comparison in fresh, dried, stir-frying and carbonized ginger," Journal of Chromatography $B$, vol. 1011, pp. 223-232, 2016.

[26] A. Schieber, P. Keller, and R. Carle, "Determination of phenolic acids and flavonoids of apple and pear by high-performance liquid chromatography," Journal of Chromatography A, vol. 910, no. 2, pp. 265-273, 2001.

[27] V. K. Singh and K. R. C. Reddy, "Validation of Lodhradi Kashaya (Ayurvedic formulation) made by traditional method and contemporary spray drier method through FTIR spectroscopy," International Journal of Pharmacy and Analytical Research, vol. 4, no. 3, pp. 386-390, 2015.

[28] S. S. Sablani, P. K. Andrews, N. M. Davies, T. Walters, H. Saez, and L. Bastarrachea, "Effects of Air drying and freeze drying on phytochemical content of conventional and organic berries," Drying Technology, vol. 29, no. 2, pp. 205-216, 2011.

[29] D. Bernard, A. Kwabena, O. Osei, G. Daniel, S. Elom, and A. Sandra, "The effect of different drying methods on the phytochemicals and radical scavenging activity of Ceylon cinnamon (Cinnamomum zeylanicum) plant parts," European Journal of Medicinal Plants, vol. 4, no. 11, pp. 1324-1335, 2014.

[30] F. Shahidi and Y. Zhong, "Novel antioxidants in food quality preservation and health promotion," European Journal of Lipid Science and Technology, vol. 112, no. 9, pp. 930-940, 2010.

[31] S. Alok, S. K. Jain, A. Verma, M. Kumar, A. Mahor, and M. Sabharwal, "Herbal antioxidant in clinical practice: A review," Asian Pacific Journal of Tropical Biomedicine, vol. 4, no. 1, pp. 78-84, 2014.

[32] J. A. Lee, S. Jang, J. H. Jun et al., "Herbal medicine (Bojungikki - tang) for allergic rhinitis. A protocol for systematic review of controlled trials," Medicine, vol. 97, no. 3, Article ID e9551, 2018.

[33] X. Zhang, F. Lan, Y. Zhang, and L. Zhang, "Chinese herbal medicine to treat allergic rhinitis: Evidence from a metaanalysis," Allergy, Asthma \& Immunology Research, vol. 10, no. 1, pp. 34-42, 2018.

[34] C. Cingi, N. Bayar Muluk, and G. K. Scadding, "Will every child have allergic rhinitis soon?" International Journal of Pediatric Otorhinolaryngology, vol. 118, pp. 53-58, 2019.

[35] J.-H. Seo, S.-O. Kwon, S.-Y. Lee et al., "Association of antioxidants with allergic rhinitis in children from Seoul," Allergy, Asthma \& Immunology Research, vol. 5, no. 2, pp. 81-87, 2013. 
[36] S. Patel, C. S. Murray, A. Woodcock, A. Simpson, and A. Custovic, "Dietary antioxidant intake, allergic sensitization and allergic diseases in young children," Allergy: European Journal of Allergy and Clinical Immunology, vol. 64, no. 12, pp. 1766-1772, 2009.

[37] S. Chou and K. Chua, "New hybrid drying technologies for heat sensitive foodstuffs," Trends in Food Science \& Technology, vol. 12, no. 10, pp. 359-369, 2001.

[38] A. Wojdyło, J. Oszmiański, and R. Czemerys, "Antioxidant activity and phenolic compounds in 32 selected herbs," Food Chemistry, vol. 105, no. 3, pp. 940-949, 2007.

[39] Y. Cheng, Q. Xu, J. Liu, C. Zhao, F. Xue, and Y. Zhao, "Decomposition of five phenolic compounds in high temperature water," Journal of the Brazilian Chemical Society, vol. 25, no. 11, pp. 21022107, 2014.

[40] K. Sharma, E. Y. Ko, A. D. Assefa et al., “Temperaturedependent studies on the total phenolics, flavonoids, antioxidant activities, and sugar content in six onion varieties," Journal of Food and Drug Analysis, vol. 23, no. 2, pp. 243-252, 2015.

[41] M. S. Rabeta and S. P. Lin, "Effects of different drying methods on the antioxidant activities of leaves and berries of Cayratia trifolia," Sains Malaysiana, vol. 44, no. 2, pp. 275-280, 2015.

[42] A. Orphanides, V. Goulas, and V. Gekas, "Effect of drying method on the phenolic content and antioxidant capacity of spearmint," Czech Journal of Food Sciences, vol. 31, no. 5, pp. 509-513, 2013.

[43] V. Goulas and G. A. Manganaris, "The effect of postharvest ripening on strawberry bioactive composition and antioxidant potential," Journal of the Science of Food and Agriculture, vol. 91, no. 10, pp. 1907-1914, 2011. 


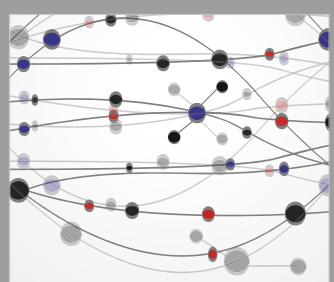

The Scientific World Journal
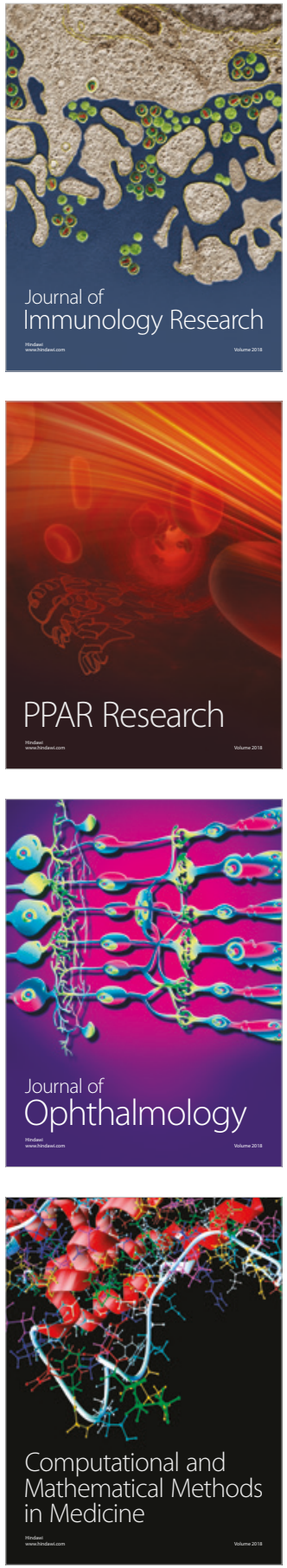

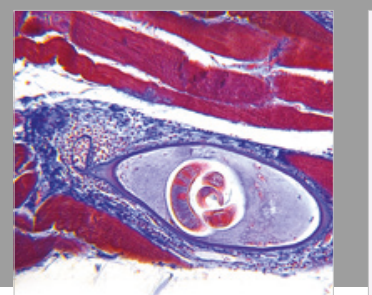

Gastroenterology Research and Practice

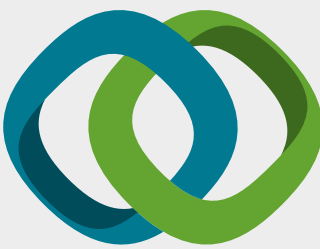

\section{Hindawi}

Submit your manuscripts at

www.hindawi.com
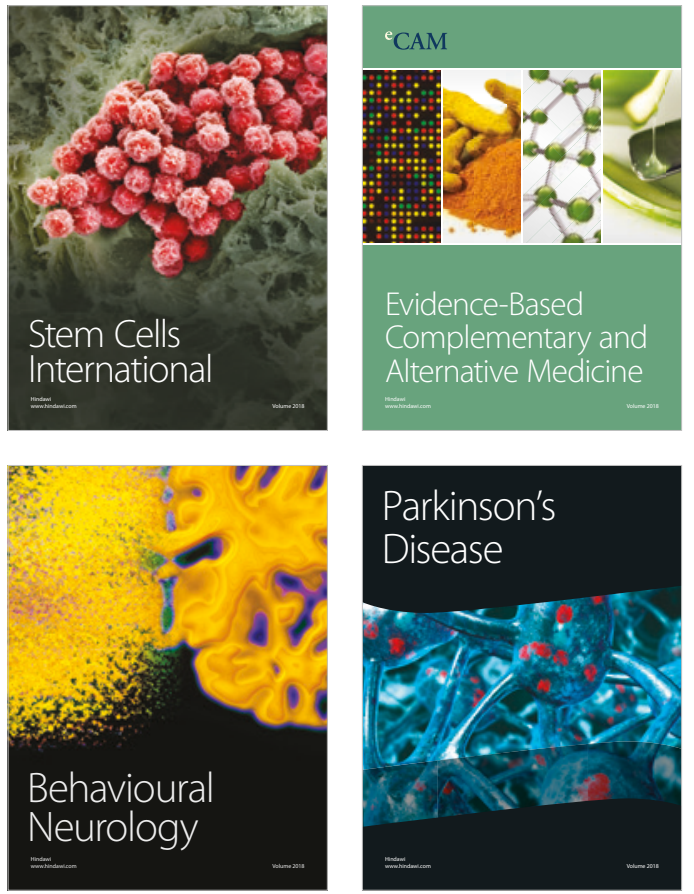

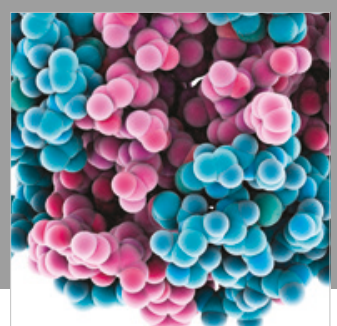

ournal of

Diabetes Research

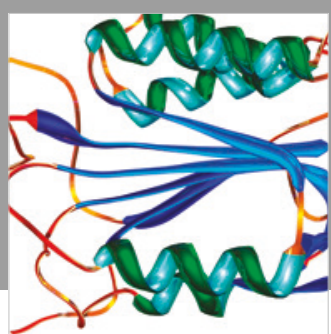

Disease Markers
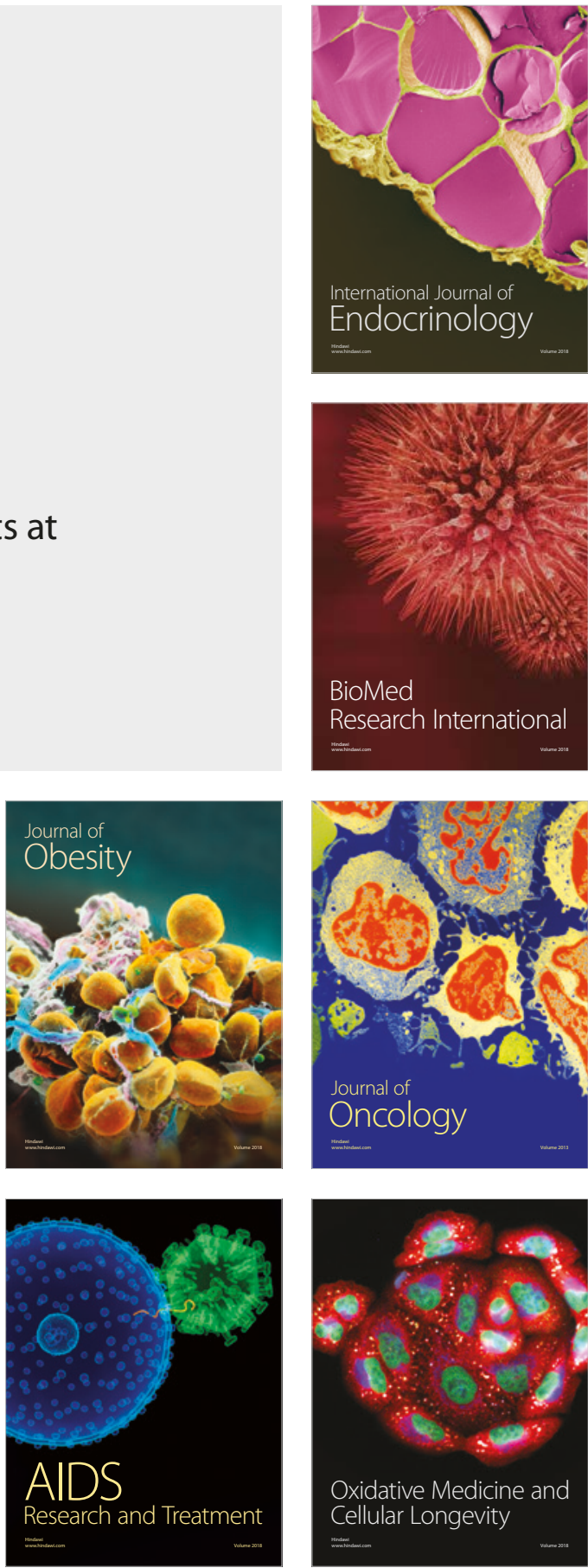